\title{
ARABLE LAND ABANDONMENT IN THE CZECH VILLAGES OF ROMANIAN BANAT AREA AND PLANT DIVERSITY IN OLD-FIELDS
}

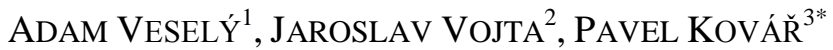 \\ ${ }^{I}$ Research Institute for Soil and Water Conservation, Žabovřeská 250, 156 27, Praha 5 - \\ Zbraslav, Czech Republic \\ ${ }^{2}$ The Silva Tarouca Research Institute for Landscape and Ornamental Gardening, \\ Květnové náméstí 391, 252 43, Průhonice, Czech Republic \\ ${ }^{3}$ Department of Botany, Faculty of Science, Charles University, Benátská 2, 128 01, Prague, \\ Czech Republic \\ *Corresponding authore-mail: pavel.kovar@natur.cuni.cz
}

Received: $2^{\text {nd }}$ November 2019, Accepted: $3^{\text {rd }}$ December 2019

\begin{abstract}
The aim of this study is to differentiate old-field plant communities along the abandonment time and/or environmental gradient in the landscape surrounded villages with established Czech settlers in Romanian Banat area conserving traditional agriculture, and to identify site factors which cause plant diversity of particular vegetation types. Study area: Wider territory centered by the village Sfânta Elena, southern Romania ( $\left(44^{\circ} 40^{\prime} \mathrm{N} ; 21^{\circ} 43^{\prime} \mathrm{E}\right)$. Methods: We collected 97 phytosociological relevés covered the same number of old-fields in the area and the following habitat parameters were measured: soil $\mathrm{pH}$, available phosphorus, total carbon and nitrogen, Heat Load Index. Software TURBOVEG / JUICE was used to collect and elaborate the data set of relevés. Old-field vegetation was classified into five basic plant communities using TWINSPAN (all the botanical material includes 291 plant species). For each community, we detected diagnostic species according to their fidelity index. The presence of mowing, grazing or burning was registered for recorded stands. Ecological preferences of each community were examined using one-way analysis of variance (ANOVA). Vegetation-environment relationships were analysed using ordination method Cannonical correspondence analysis (CCA) in CANOCO for Windows (version 4.5) to find the main variability gradients within the dataset. Scatter plot relationships between variables were constructed. Main results and conclusions: Dependence of number of species (alpha diversity) on the abandoned field's age exhibits an unimodal shape of this relationship with the maximum peak of species diversity in plant stands aged approximately 13 years. The most importnat ecological factors and/or type of management in the relationship to the old-field plant composition show the following significance order: available phosphorus content in the soil $(\mathrm{P})$, total nitrogen content in the soil $(\mathrm{N})$, presence of burning, length of abandonment (old-field age), carbon/nitrogen ratio in the soil $(\mathrm{C} / \mathrm{N})$. Other parameters (grazing, mowing, zero management) do not demonstrate effective impact according to our dataset and seem to be equal to the absence of burning.
\end{abstract}

Keywords: Romanian Banat; traditional agriculture; landscape change; land abandonment; old-field age; grazing; mowing; burning; soil chemistry; community level; 
Veselý A., Vojta J., Kovář P.: Arable land abandonment in the Czech villages of Romanian Banat area and plant diversity in old-fields

plant species diversity; evenness; secondary succession; grassland; shrubland; clonal expansive dominants

\section{INTRODUCTION}

Impact of arable land abandonment on various parameters of the research model area of the Romanian Banat territory is serious in such levels as landscape architecture, species diversity of vegetation or connectivity of habitats (Maděra et al., 2014). The basic reason of our interest is relatively fast land transformation during the last decades caused by re-escaping of Czech inhabitants from this area to their native country (Czech Republic) in the last 30 years. Economic transformation in the eastern European countries implied the loss of traditional way of living (decline of traditional agriculture sufficiency, former job opportunity of local people in heavy metal mines). These circumstances led to reduced arable land proportion approx. about one-half during last 40 years.

The variability of regional landscape segments is done by the morphologically rich karst relief, geology, soils and climatic zonation (Maděra et al., 2014). Habitats richness is further enhanced by specific traditional agriculture based on private land ownership and forestry (applied at least for hundred years: combination of short cutting cycle and forest grazing). Therefore, the question is whether the recent abandonment of the area would compromise the diversity in the landscape. Abandonment of plowed field means a new habitat for plant and animal species, ie. a new chance for biota to colonize the renewed niche space. Old-field habitat represents the stage of plant growth between bare ground and forest climax community and it has two distinct vegetation stages: grassland and shrubland. The grassland stage occurs in one to several years old-fields and consists primarily of grasses and broad-leaved flowering plants. The shrub stage of an old-field develops as the grassland progresses to a stage dominated by at least $10 \%$ of woody plants; primarily seedling and sapling size (e.g. Greenfield, 2005). We can see two types of disturbances causing changes in vegetation: They can be evoked by natural causes such as extreme meteorological situations, or by artificial (human) activities such as mowing, cutting, or using chemical compounds. The initial stage of vegetation succession consists of a relatively low number herb species, most of which are annuals. Pioneer species within colonization are usually characterized by having long-lived seeds capable of remaining dormant in the soil for many years, long-range dispersal ability, and capability to utilize resources rapidly, allowing them to grow and reproduce in accelerating regime mainly for one to three years. This type of plants is highly tolerant to full sunlight. Species diversity is rather low and this plant stand lacks vertical structural complexity. When an old-field is several years old, perennial grasses and herbs gradually replace the annual and biennial species of the initial stages of secondary succession. Still later in vegetation succession, woody plants - mainly shrubs begin to grow and both vertical structural complexity and species diversity increase.

The assemblage of shrubs and herbaceous plant forms creates a greater diversity of food sources and habitats for a range of animal species. The seedlings of most tree species of the potential climax community (forest) are shade-tolerant, so that they can begin to grow under the cover of shrubs and create the subcanopy layer beneath the shrub canopy (e.g., Bazzaz, 1975; De Steven, 1991; Wilsey et Potvin, 2000; Schmitz et al., 2006). Deforestation and agricultural landscape fragmentation and/or human disturbances in general usually result in ecosystem mosaic with ecological regimes specific for the particular types of patches (incl. human management practices). Diversity pattern variations during succession are due to the selection of life history strategies under different types of disturbances (e.g. Denslow, 1980; Dinnage, 2009). There are the authors maintaining that plant diversity and 
composition during the succession follow a fieldcrop's abandonment change in predictable ways (Bomberger et al., 1983; Siemann et al., 1999). It seems to be true when the long-term abandonment is absolute (which situation frequently occurs in developed countries with the decline of their own agricultural production due to market globalization). Such situation is known, e.g. from central Europe where studies of the old-field succession could differ trends into dry, mesic or wet seres (Osbornová et al., 1990; Štolcová, 2002; Prach et al., 2007). However, low predictability of cyclic or generally irregular development of old-field communities is common under impacts of pasture, mowing, burning or mixture of the all mentioned kinds of disturbances which is usual in eastern European countries including Romania (Ruprecht, 2005; Csergö et Demeter, 2012).

The questions of the study: What is the variability of old-field communities in the landscape of Banat area? What is the plant species diversity of different old-fields? Is the differentiation of old-fields influenced by specific factors (old-field age, type of management, soil conditions)?

\section{METHODS}

\section{Sampling and data collection}

Phytosociological relevés were recorded approximately in a central part of every sampled old-field. Sampling area was 5 x $5 \mathrm{~m}$. Territory of interest was centered by the village Sfânta

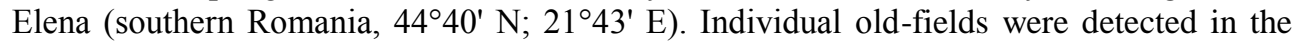
ortophotomap (Fig. 3). All the relevés were obtained during May - June 2012. The number of records is 97 . A seven-grade scale of abundance was used for the species assessment within the stands (Braun-Blanquet, 1928): $\mathrm{r}-1$ plant individual and/or nearly zero abundance; + rare plant, however, maybe several individuals of very small abundance; 1 - up to $5 \% ; 2-6$ $25 \% ; 3-26-50 \% ; 4-51-75 \% ; 5-76-100 \%$. Coordinates of the plots were measured by GPS as well as elevations. The old-field age together with the presence of mowing or grazing was found out separately from the structural features of current stands by interviewing local people, in optimal case their owners. Heat Load Index (HLI) was calculated from topographic site features (slope, orientation); it represents a complex indicator of the habitat nature, mainly microclimatic conditions of any vegetation record (McCune et Keon, 2002). Presence of applied burning was possible to register directly in the field by carbonized residues.

Evenness as a tool of the species diversity assessment in phytosociological relevés was calculated according to Simpson index, where $\mathrm{E}=$ species evenness, $\mathrm{S}=$ relevé number of species, $\mathrm{P}=$ relative abundance of the $\mathrm{i}$-species.

$$
E=\frac{1}{\sum_{i=1}^{S} p_{i}^{2}} \times \frac{1}{S}
$$

The names of plant taxa are used according to Ciocârlan (2000).

\section{Data analysis/statistics}

The computer software package TURBOVEG / JUICE (Hennekens et Schaminée, 2001; Tichý, 2002) was used for the processing of phytosociological data and/or the data set of relevés collected from the old-fields (http://www.synbiosys.alterra.nl/turboveg/, http://www.sci.muni.cz/botany/juice.htm). The youngest successional stages of abandoned arable land (1-2 years old) were left out, among others due to their rare occurence. Synoptic table (Table 1) was constructed with the help of Modified Twinspan classification (Roleček 
Veselý A., Vojta J., Kovář P.: Arable land abandonment in the Czech villages of Romanian Banat area and plant diversity in old-fields

et al., 2009). Basic analyses were performed in programmes Microsoft Excel 2007 and Statistica.

Dependence between different vegetation types on measured habitat factors was examined using one-way analysis of variance (ANOVA). Constrained ordination method - Cannonical correspondence analysis (CCA) in CANOCO for Windows (version 4.5, Microcomputer power, Ithaca, NY, US; ter Braak et Šmilauer, 2002) was used to find the main variability gradients within the dataset and scatter plot relationships between variables were drawn.

\section{Soil analysis}

Soil samples for chemical analysis were taken from each one of the all phytosociological relevés. They were obtained from the depth of $5 \mathrm{~cm}$, then homogenized and sieved. Chemical analyses of available phosphorus, total nitrogen and total carbon, and active $\mathrm{pH}$ were done. Analyses of available $\mathrm{P}$, and total $\mathrm{C}$ and $\mathrm{N}$ were performed in laboratories of the Institute of Botany, Czech Academy of Sciences, in Průhonice. Active soil pH analysis was performed in the Geobotanical laboratory, Department of Botany, Faculty of Science, Charles University.

$\underline{\mathrm{pH}}$

$5 \mathrm{ml}$ of fine soil was extracted for half an hour in orbital shaker with $25 \mathrm{ml}$ of extracing solution (boiled deionized water). After 90 minutes, $\mathrm{pH}$ of suspension was measured with combined $\mathrm{pH}$ electrode with temperature correction on WTW Multilab 540 device with electronic output of collected data.

\section{C and $\mathrm{N}$}

Soil sample that was homogenized and ground to soil particles size lower than $0.1 \mathrm{~mm}$ was dried at $60^{\circ} \mathrm{C}$ and weighed to a tin containers, designed for the used device $(10-30 \mathrm{mg}$ weight, depending on the expected content of the elements) and applied to the analyzer Carlo Erba NC 2500 combustion tube. The sample is burned here in a stream of pure oxygen at a temperature of $1000{ }^{\circ} \mathrm{C}$, under the presence of chromium trioxide as a catalyst. The resulting carbon and nitrogen oxides after passing through the combustion tube are led through a reduction tube $\left(800^{\circ} \mathrm{C}, \mathrm{Cu}\right.$ load $)$ to a separation column where water and carbon dioxide are separated. Helium is used as the carrier gas. The content of separated oxides is determined by a conductivity detector. Clarity Lite software from DataApex is used for signal evaluation.

\section{Available phosphorus}

The soil samples (soil particle size $<2 \mathrm{~mm}$ ) are extracted with a solution Me III (at a ratio of $5 \mathrm{~g}$ of soil per $50 \mathrm{ml}$ ). After filtration, the determination is performed by a photometric method based on the reaction of phosphates with ammonium molybdate using a reaction mixture with sulfuric acid, ascorbic acid and antimony potassium tartrate. The absorbance of the resulting blue color is measured by a UV-vis spectrometer Unicam UV-400 at $750 \mathrm{~nm}$.

\section{RESULTS}

\section{Classification of old-field communities}

Synoptic table (Table 1) shows the result of Modified Twinspan classification (Roleček et al., 2009) of the all relevé set collected in the field. It means 5 community types based on identification of diagnostic species with the help of fidelity index $(\varphi)$. A relevant question is: Do the established vegetation types differ in their environmental parameters? ANOVA 
confirmed that significant differences $(\mathrm{p}<0,05)$ among five distinguished old-field communities exist in the following characteristics: old-field age (time of abandonment), inclination degree, heat load index, soil $\mathrm{pH}$, total $\mathrm{C}$ and $\mathrm{N}$ content in the soil, $\mathrm{C} / \mathrm{N}$ ratio, and content of available phosphorus. Of course, the vegetation types differ in their biological characteristics: number of plant species, abundance of the shrub and herb layer. Result implying from the data show that the most different of the all other vegetation in the analyzed parameters is vegetation type 1 occuring in the old-fields of high age, mostly on the slopes and soils with relatively high content of organic matter, and high $\mathrm{pH}$ (Fig. 1).

Table 1: Twinspan classification of the old-field relevé set resulted in 5 community types based on identification of diagnostic species with the help of fidelity index $(\varphi)$.

As diagnostic species are taken those present species with $\varphi<20$ (light green ground); as highly diagnostic ones are considered species with $\varphi<50$ (dark green). The Fisher's exact test was used $(\mathrm{p}=0,001)$ as a significance test of the species diagnostic value. This synoptic table includes the overview of diagnostic species, theit frequency and values of $\varphi$ for each of the all communities. Delimitation of communities was calculated with the help of Sørensen coefficient (minimum difference is 0.6 ).

\begin{tabular}{|c|c|c|c|c|c|}
\hline Vegetation type & 1 & 2 & 3 & 4 & 5 \\
\hline Number of relevés in each veg. type & 4 & 35 & 8 & 10 & 40 \\
\hline Poa angustifolia & 96.6 & --- & --- & --- & --- \\
\hline Rubus sp. & 85 & --- & --- & --- & --- \\
\hline Achillea pannonica & 84 & --- & --- & --- & --- \\
\hline Orlaya grandiflora & 84 & --- & --- & --- & --- \\
\hline Silene alba & 84 & --- & --- & --- & --- \\
\hline Koeleria pyramidata & 78.6 & --- & --- & --- & --- \\
\hline Verbascum lychnitis & 75.7 & --- & --- & -- & --- \\
\hline Chondrilla juncea & 75.7 & --- & --- & --- & --- \\
\hline Lepidium campestre & 70 & --- & --- & --- & --- \\
\hline Arenaria serpyllifolia & 70 & --- & --- & --- & --- \\
\hline Luzula campestris & --- & 52.2 & --- & --- & --- \\
\hline Helianthemum nummularium & --- & 51.8 & --- & --- & --- \\
\hline Viola canina & --- & 51.6 & --- & --- & --- \\
\hline Trifolium montanum & --- & 49 & --- & --- & --- \\
\hline Chamaecytisus glaber & --- & 48.9 & --- & --- & --- \\
\hline Veronica jacquinii & --- & 46.6 & --- & --- & --- \\
\hline Brachypodium pinnatum & --- & 45.3 & --- & --- & --- \\
\hline Filipendula vulgaris & --- & 44.8 & --- & --- & --- \\
\hline Polygala comosa & -- & 44.7 & --- & --- & --- \\
\hline Genista ovata & --- & 43.9 & --- & --- & --- \\
\hline Anthoxanthum odoratum & --- & 41.8 & --- & -- & --- \\
\hline Ferulago sylvatica & --- & 40.8 & --- & --- & --- \\
\hline Betonica officinalis & --- & 40.8 & --- & --- & --- \\
\hline Knautia arvensis & --- & 39.8 & --- & --- & --- \\
\hline Trifolium alpestre & --- & 28.9 & --- & --- & --- \\
\hline Carex caryophyllea & --- & 28.4 & --- & --- & --- \\
\hline
\end{tabular}


Veselý A., Vojta J., Kovář P.: Arable land abandonment in the Czech villages of Romanian Banat area and plant diversity in old-fields

Dianthus carthusianorum

Salvia pratensis

Teucrium chamaedrys

Thymus pannonicus

Sherardia arvensis

Reseda lutea

Convolvulus arvensis

Salvia nemorosa

Capsella bursa-pastoris

Rumex crispus

Taraxacum officinale

Festuca rubra

Poa trivialis

Viola arvensis

Leucanthemum vulgare

Carlina vulgaris

Rubus caesius

Trisetum flavescens

Agrimonia eupatoria

Hieracium sp.

Dactylis glomerata

Hypochaeris radicata

Erigeron annuus

Daucus carota

Festuca valesiaca

\begin{tabular}{|c|c|c|c|c|}
\hline --- & 25.7 & --- & --- & --- \\
\hline --- & 24.7 & --- & --- & --- \\
\hline --- & 22.1 & --- & --- & --- \\
\hline --- & 20.4 & --- & --- & --- \\
\hline --- & --- & 56.9 & --- & --- \\
\hline --- & --- & 56.9 & --- & --- \\
\hline --- & --- & 50.2 & 40.2 & --- \\
\hline --- & --- & --- & 59.8 & --- \\
\hline --- & --- & --- & 59 & --- \\
\hline --- & --- & --- & 57.9 & --- \\
\hline --- & --- & --- & 57.7 & --- \\
\hline --- & --- & --- & 57.5 & --- \\
\hline --- & --- & --- & 40.6 & --- \\
\hline --- & --- & --- & 25.5 & --- \\
\hline --- & --- & --- & --- & 48.3 \\
\hline --- & --- & --- & --- & 46.6 \\
\hline --- & --- & --- & --- & 36.2 \\
\hline --- & --- & --- & --- & 34.3 \\
\hline --- & --- & --- & --- & 33.8 \\
\hline --- & --- & --- & --- & 31.9 \\
\hline --- & --- & --- & --- & 30.6 \\
\hline --- & --- & --- & --- & 29.7 \\
\hline --- & --- & --- & --- & 29 \\
\hline --- & --- & --- & --- & 21.7 \\
\hline --- & --- & --- & --- & 18 \\
\hline
\end{tabular}

Photo 1: Land mosaic created by outlines of abandoned fields variously old (SE surroundings of the village Sfânta Elena, Southern Romania). Photo Adam Veselý

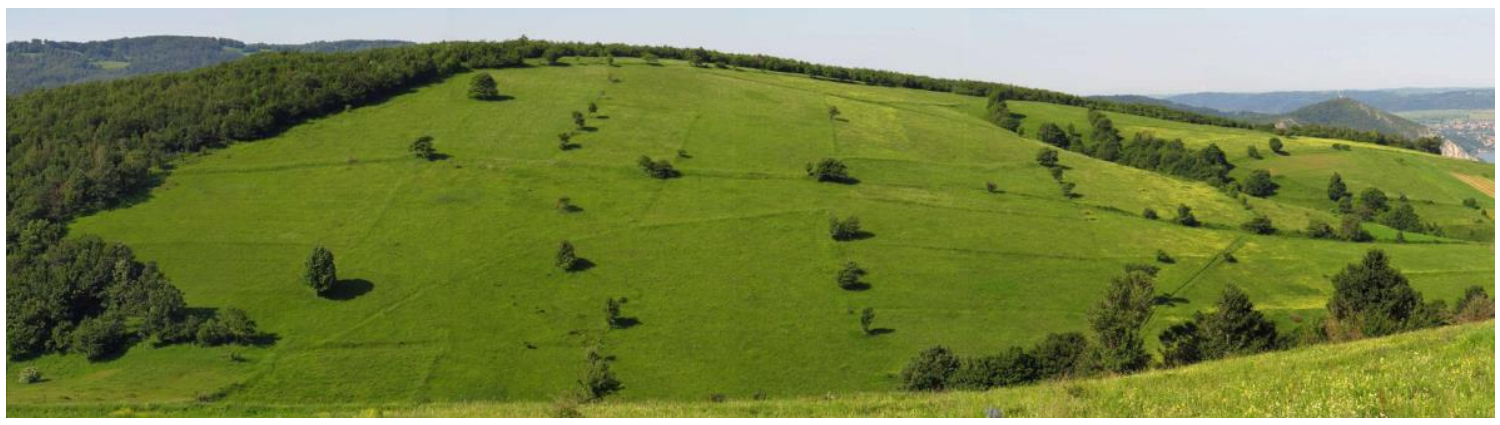


Fig. 1: Environmental variables in dependence on vegetation types 1 - 5. Mean values are plotted with standard deviation.
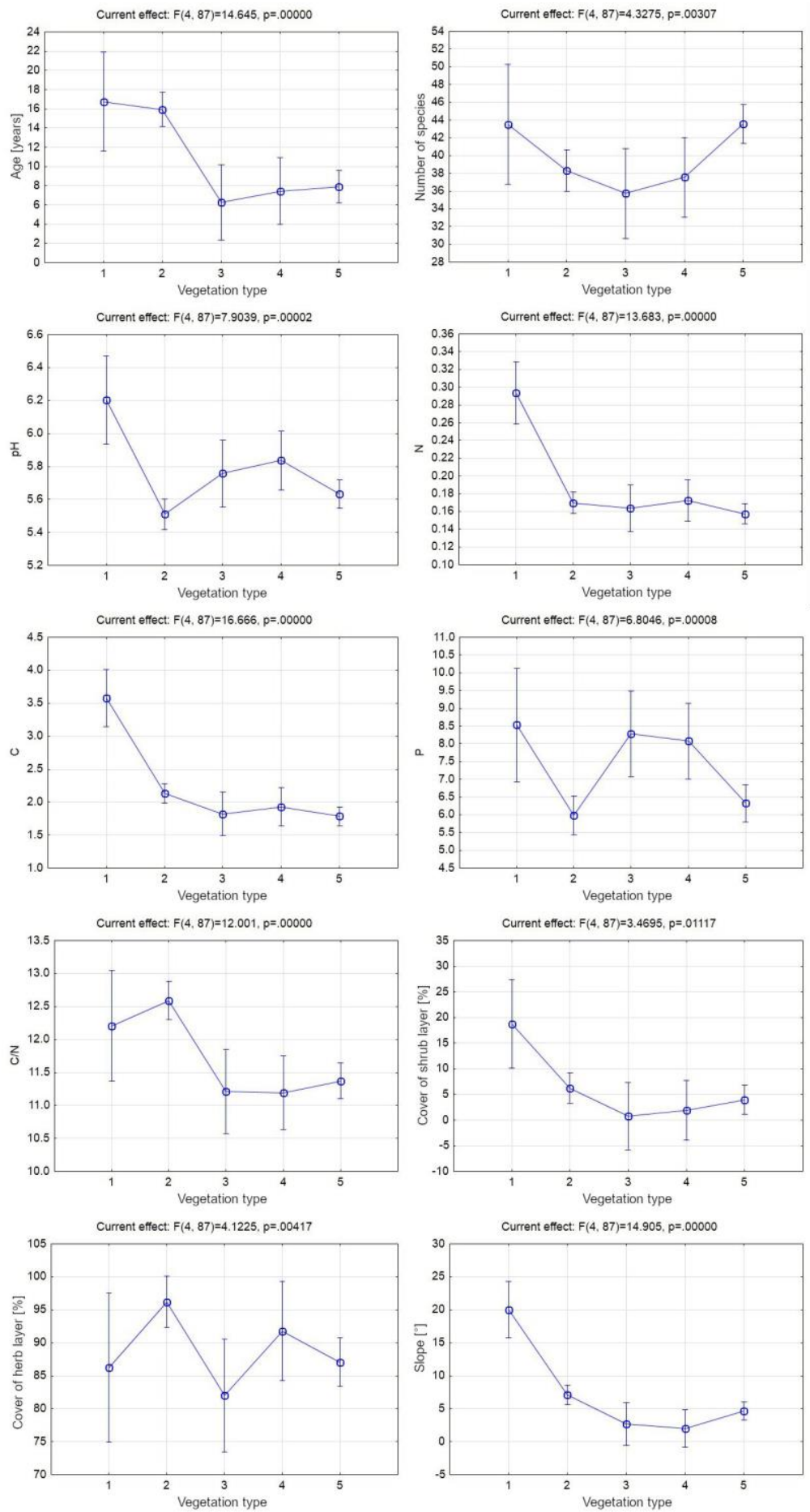
Veselý A., Vojta J., Kovář P.: Arable land abandonment in the Czech villages of Romanian Banat area and plant diversity in old-fields

\section{Environmental relationships and community level}

Unconstrained multivariate correspondence analysis (CA) suggests the importance of measured ecological factors for shaping of delimited old-field communities (Fig. 2). This figure includes the individual relevés of the old-fields divided into vegetation types labelled by colours together with environemtal variables displayed passively. There are chosen those variables that exhibited the significant influence on the species composition of communities within constrained multivariate analysis. Also this analysis demonstrates distinct difference of the vegetation type 1 in the frame of present old-field communities. The vegetation types 2 - 4 are distributed more or less continuously along the first ordination axis representing the most important environmental gradient. In spite of this, the vegetation type 5 is originated by gradual change of plant species composition.

Fig. 2: CA analysis of the relevé dataset. Affiliation to vegetation types is labelled by colours. Explaining variables with significant influence to plant species composition of communities are the following: available phosphorus content in the soil $(\mathrm{P})$, total nitrogen content in the soil $(\mathrm{N})$, presence of burning, length of abandonment (age), carbon/nitrogen ratio in the soil $(\mathrm{C} / \mathrm{N})$.

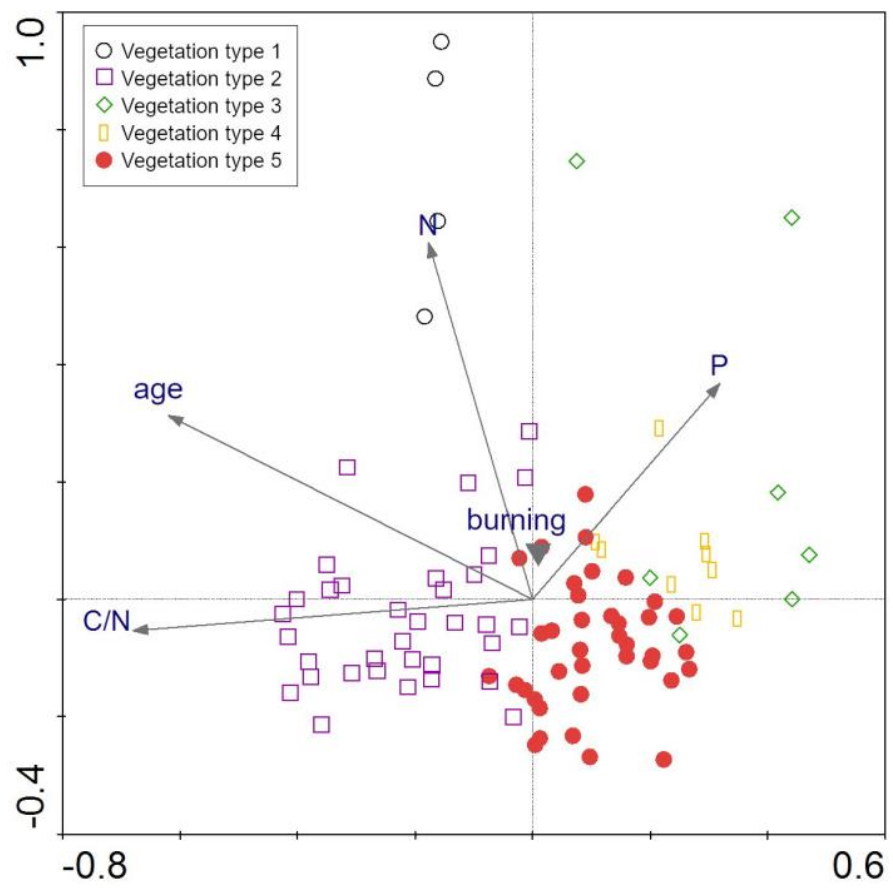

Brief summarization of basic features of the abandoned arable soils follows:

Young communities on relatively poor soils in nutrients, with higher proportion of sandy or skeletal fraction, usually following cereals, (floristically close to phytosociological alliance Sherardion): Sherardia arvensis, Reseda lutea, Convolvulus arvensis.

Younger, only several years old communities on nutrient rich soils (floristically close to phytosociological alliance Convolvulo-Agropyrion repentis): Salvia nemorosa, Capsella bursa-pastoris, Rumex crispus, Taraxacum officinale, Festuca rubra, Poa trivialis, Convolvulus arvensis, Viola arvensis. 
Several years old, periodically again cultivated old-fields with prevailing mesophile species including shrubs adapted on disturbances (e.g., Rubus caesius) on soils of middle fertility with some sandy or skeletal part: Leucanthemum vulgare, Carlina vulgaris, Rubus caesius, Trisetum flavescens, Agrimonia eupatoria, Dactylis glomerata, Hypochaeris radicata, Erigeron annuus, Daucus carota, Smyrnium perfoliatum, Carduus nutans, Festuca valesiaca, Achillea collina, Rhinanthus rumelicus, Vicia tenuifolia.

More or less diffusive and/or partly open stands on shallow soils under the influence of mild intensity of disturbance (pastures), the oldest herbal old-field communities (floristically close to phytosociological alliance Chrysopogono-Danthonion): Brachypodium pinnatum, Filipendula vulgaris, Viola canina, Trifolium montanum, Chamaecytisus glaber, Veronica jacquinii, Polygala comosa, Genista ovata, Anthoxanthum odoratum, Ferulago sylvatica, Knautia arvensis, Betonica officinalis, Trifolium alpestre, Hypochaeris maculata, Chrysopogon gryllus.

Half-open old stands in mosaics of pastures and forests, usually on the slopes around former sheep shelters, probably influenced by frequent burning, on hallow soils with higher content of organic matter (floristically close to phytosociological alliance Onopordion acanthii or Dauco-Melilotion): Poa angustifolia, Rubus sp. div., Achillea pannonica, Orlaya grandiflora, Silene alba, Koeleria pyramidata, Verbascum lychnitis, Chondrilla juncea, Lepidium campestre, Arenaria serpyllifolia.

Fig. 3: Map of the Sfânta Elena surroundings with highlighted old-fields covered by the investigation. Vegetation types are distinguished by colours. Groups of clusters differentiated in constrained multivariate analysis as covariates are circled.

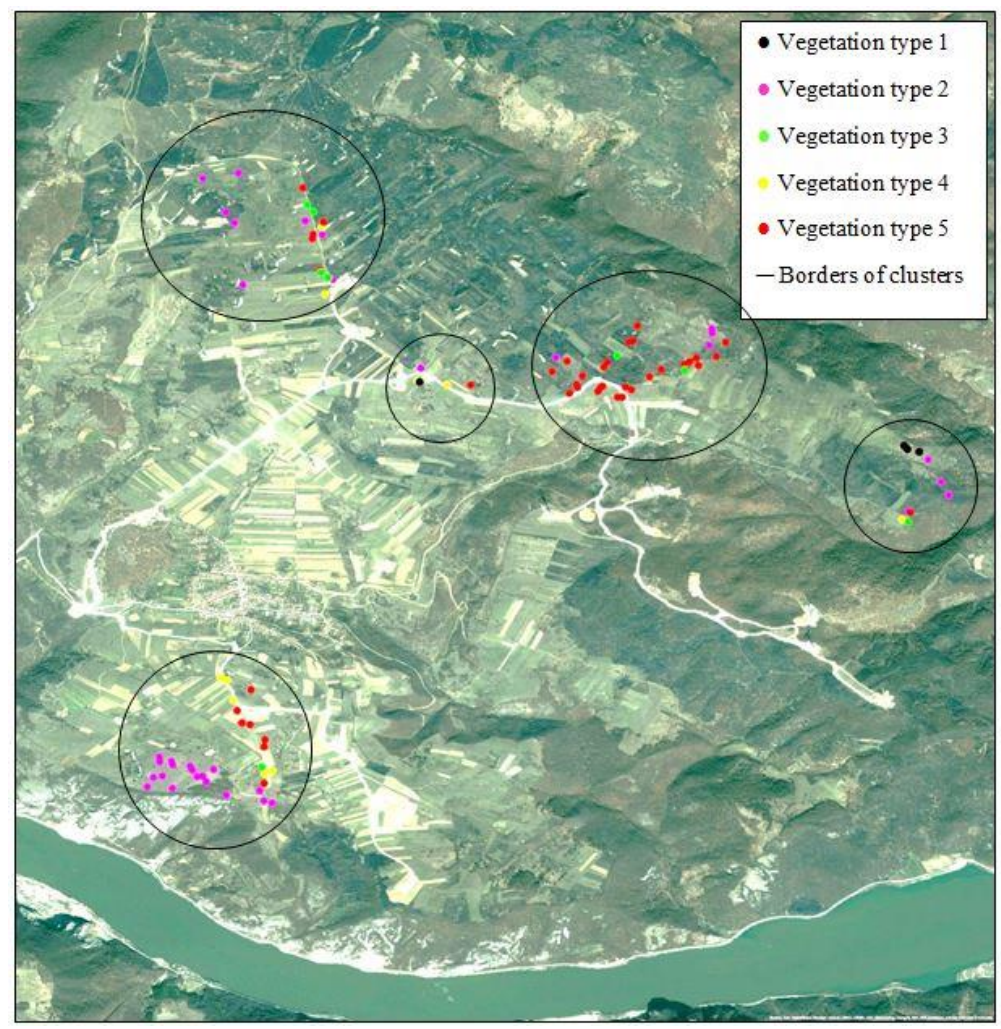


Veselý A., Vojta J., Kovář P.: Arable land abandonment in the Czech villages of Romanian Banat area and plant diversity in old-fields

\section{Biodiversity and external factors}

Total number of phanerogams recorded in the frame of 97 relevés is 291 (Veselý, 2016). Direct gradient analysis, CCA (Fig. 4) depicts how particular ecological factors and/or type of management influence plant stand composition. In general, the highest significance of influence is exhibited by the soil chemistry. We can see that age of the old-fields is weakly correlaed with $\mathrm{C} / \mathrm{N}$ ratio but the effect of $\mathrm{C} / \mathrm{N}$ ratio is nearly two times stronger in comparison of the abandonment time. Representatives of clonal plants (mostly grasses) and seedlings of woody perennials create predominantly the group of plants predisposed these conditions indicating elder stages of secondary succession (the role of woody species in the old-fields is treated in more details by Kovář et al., 2014). In spite of this pattern, mostly annuals and heliophytes are grouped within direction of higher available soil phosphorus content. Burning as a kind of disturbance is indicated by presence of mixture of plant adaptive strategies from short-lived ephemerophytes to resistent woody representatives.

\section{Fig. 4: CCA for plant species and old-field variables (age, burning, parameters of the soils: total $N$, available $P, C / N$ ratio).}

Key to abbreviations of species used in Fig. 4: Agrieup - Agrimonia eupatoria, Agrosto - Agrostis stolonifera, Achimil - Achillea millefolium, Anthodo - Anthoxanthum odoratum, Avencom - Avenula compressa, Bracpin - Brachypodium pinnatum, Calaepi - Calamagrostis epigejos, Carecar - Carex caryophyllea, Convarv - Convolvulus arvensis, Cratsp. - Crataegus sp. div., Convarv - Convolvulus arvensis, Dactglo - Dactylis glomerata, Dauccar - Daucus carota, Diancar - Dianthus carthusianorum, Erigann - Erigeron annuus, Euphtau - Euphorbia taurinensis, Festval - Festuca valesiaca, Filivul Filipendula vulgaris, Fragvir - Fragaria viridis, Galialb - Galium album, Hiersp. - Hieracium sp. div., Hypomac - Hypericum maculatum, Hypomac - Hypochaeris maculata, Hyporad - Hypochaeris radicata, Knauarv - Knautia arvensis, Lathtub - Lathyrus tuberosus, Leucvul - Leucanthemum vulgare, Luzucam Luzula campestris, Planlan - Plantago lanceolata, Poacom - Poa compressa, Poapra - Poa pratensis, Potearg - Potentilla argentea, Pyruspe - Pyrus communis, Rhinale - Rhinanthus alectorolophus, Rosasp. - Rosa sp. div., Rubucae - Rubus caesius, Salvpra - Salvia pratensis, Salvver - Salvia verticillata, Sangmin Sanguisorba minor, Taraoff - Taraxacum officinale, Teuccha - Teucrium chamaedrys, Thympan - Thymus pannonicus, Thympul - Thymus pulegioides, Trifalp - Trifoilum alpestre, Trifmon - Trifolium montanum, Verojac - Veronica jacquinii, Vicisat - Vicia sativa; indexes: 5 - shrub layer, 6 - herb layer

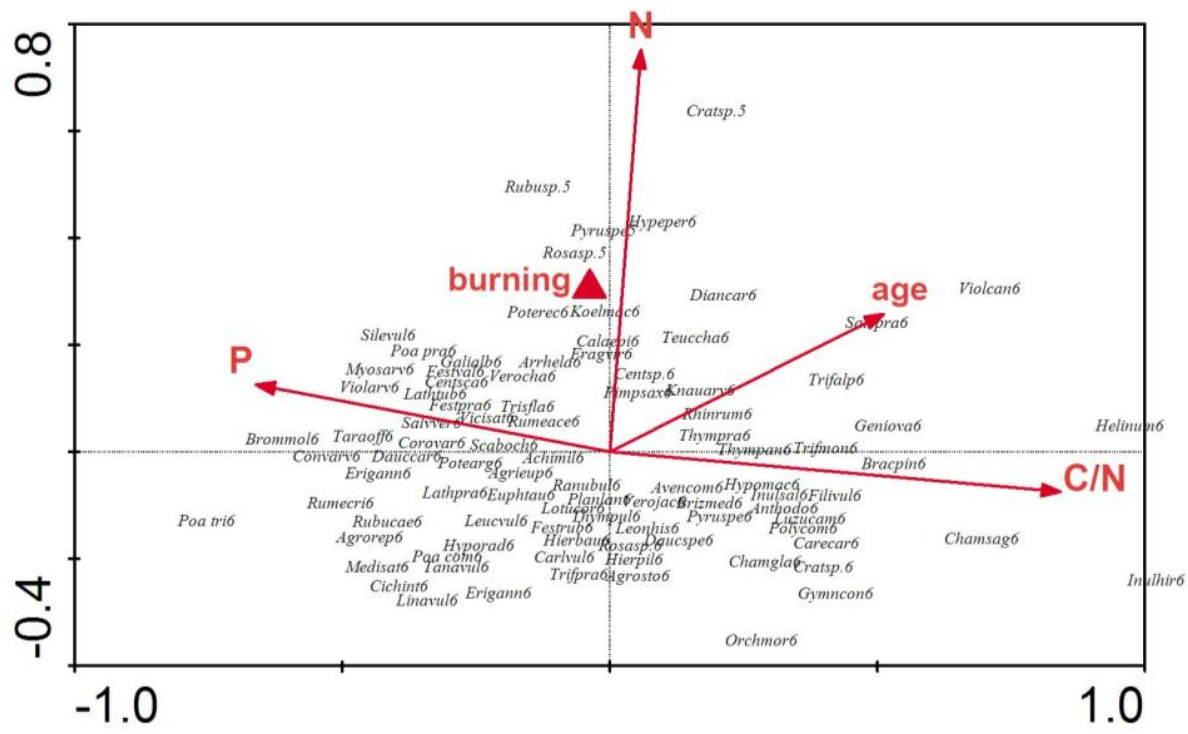


Another way how to illustrate distribution of data variability in relation to the old-field community construction is represented by the Venn diagram (Fig. 5). Direct multivariate analysis CCA shows that most of the species data variability was explained by the carbon/nitrogen ratio of soils, followed by available soil phosphorus, total soil nitrogen, burning management and age of the abandoned field. Those five environmental variables explain $12.9 \%$ of species data variability. High Load Index (HLI) was included into the testing, however, it turned out non-significantly in its effect.

Fig. 5: Analysis of those environmental variables influencing significantly species composition in the old-fields (commentary to the CCA analysis see in the text).

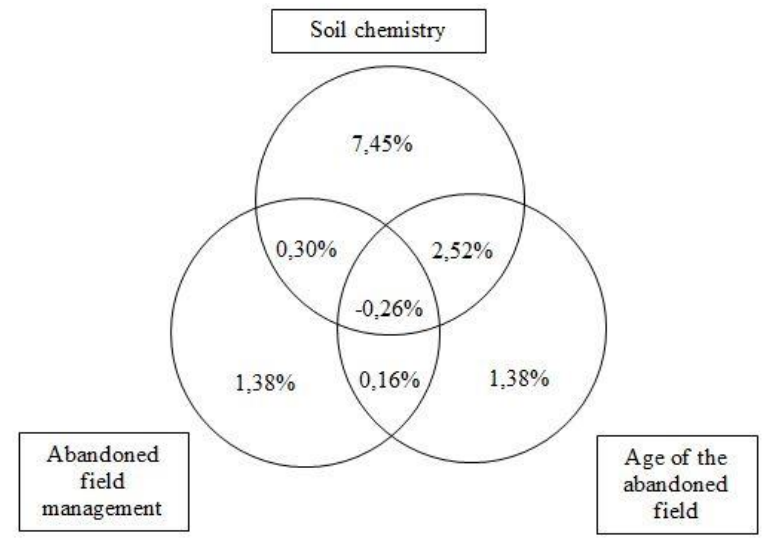

\begin{tabular}{l|l} 
& Explained variability [\%] \\
\hline \hline $\mathrm{C} / \mathrm{N}$ & 2,8 \\
$\mathrm{P}$ & 2,2 \\
$\mathrm{~N}$ & 1,9 \\
Buming management & 1,4 \\
Age of the abandoned field & 1,4 \\
\hline \hline Total variability explained by the model & $\mathbf{1 2 , 9}$ \\
Variability explained by specific variables & 9,7 \\
Explained variability not assigned to specific variables & 3,3
\end{tabular}

Special feature of diversity is represented by evenness of plant species composition of a stand. This vegetation parameter illustrates the degree of uniform pattern in species distribution within a community. Calculation of the index of evenness includes both number of species and their abundances. It is possible to assume that old-fields with strong dominants are poorer in species number than old-fields without distinct dominant (Osbornová et al., 1990). Our data agree with this expectation. Plants as Brachypodium pinnatum, Vicia tenuifolia, Calamagrostis epigeios or Agropyron repens belong to the most frequent dominants in the region. Interesting fact is that evenness in local old-fields is not connected with their age and/or time of abandonment, i.e., that dominants don't assert more on elder old-fields than on the younger ones (Fig. 6). Evenness shows only clear dependence on the $\mathrm{C} / \mathrm{N}$ ratio in the soils (Fig. 7). This parameter can be influenced by development of shrubby individuals and/or shrubby floor (exhausting of $\mathrm{N}$ from the substrate, supplying the soil by $\mathrm{C}$ through decomposition of leaf litter) on one hand, and artificial enrichment by $\mathrm{N}$ fertilizers in cultivated fields on the other. 
Veselý A., Vojta J., Kovář P.: Arable land abandonment in the Czech villages of Romanian Banat area and plant diversity in old-fields

Fig. 6: Relationship of plant species number to the evenness in old-fields

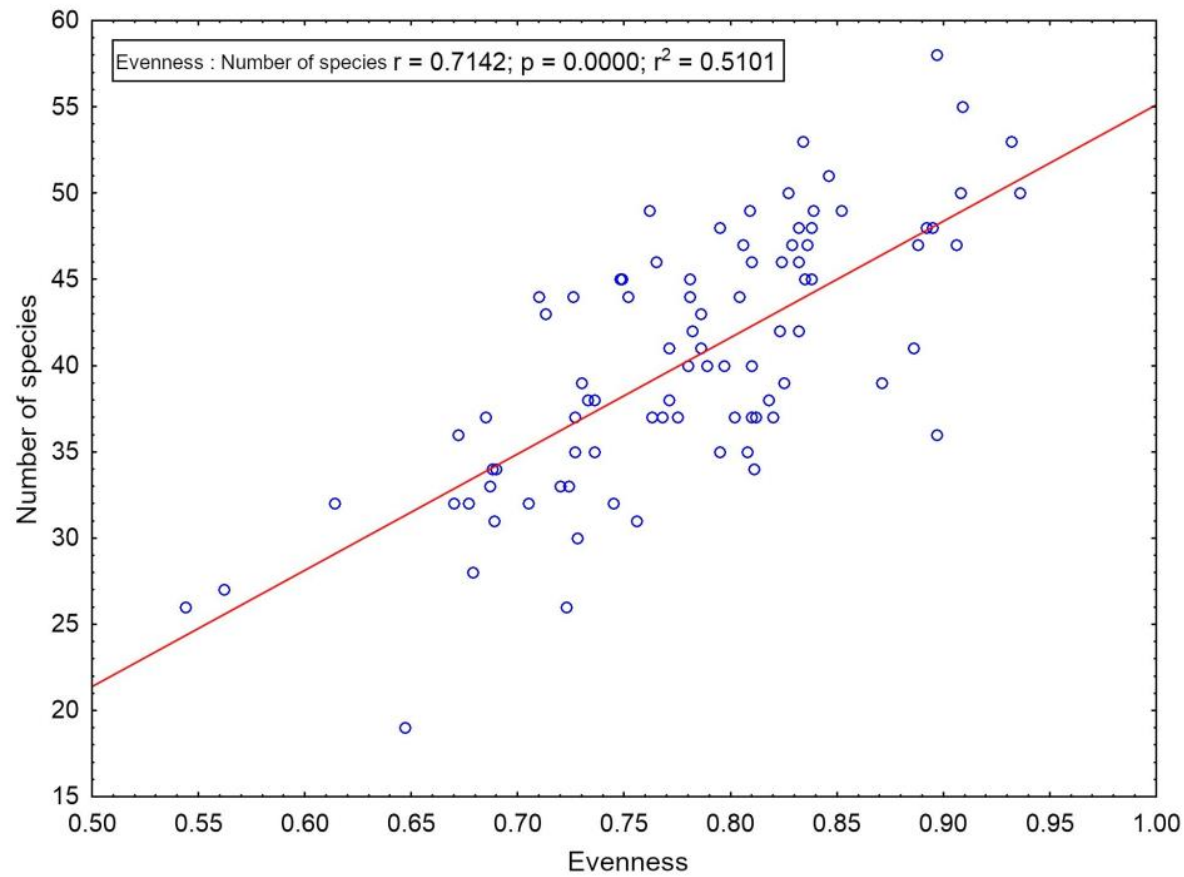

Fig. 7: Relationship of evenness to the soil $\mathrm{C} / \mathrm{N}$ ratio.

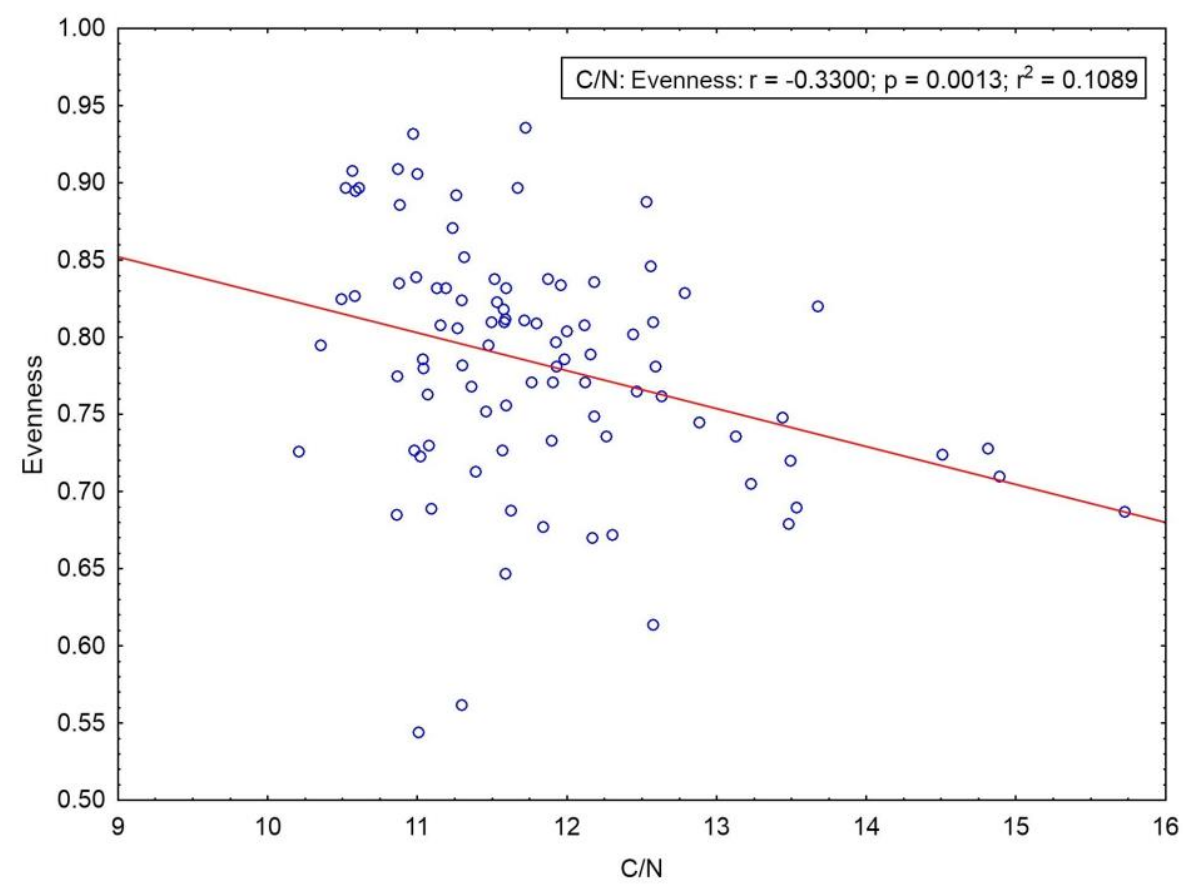




\section{Secondary succession and plant species groups}

Successional trajectory from open abandoned fields to the stands with high biodiversity spread among architecturally differentiated floors (herb and shrub layers) could be complicated process because of presence/absence of aggressive weeds or expansive dominants (such as, e.g., clonal grasses). The most frequent example is the case of dissemination of Calamagrostis epigeios with the serious impact on plant diversity of old-fields (Fig. 8). In spite of expansive behaviour of Calamagrostis epigeios the occurrence of some species valuable from the nature protection viewpoint were registered at the same old-fields (such as the orchid Gymnadenia conopsea, or more rarely G. densiflora, Orchis morio, O. coriophora, O. mascula, Listera ovata). High diversity is exhibited by relatively uncommon weeds (e.g., Agrostemma githago, Ranunculus arvensis, Vulpia myuros, Bifora radians) which is assigned to low level of biocide application and traditional way of sowing (Maděra et al., 2014). Also invasive plant species occupy niches in old-fields (the most frequent: Erigeron annuus and Erigeron annuus subsp. strigosus) as well as common neophytes (e.g., Cirsium arvense)( (Pyšek et al., 2012). In general, major dominance in the local old-field communities is rather exceptional.

Fig. 8: Dependence of plant species number on the Calamagrostis epigejos-abundance in old-fields

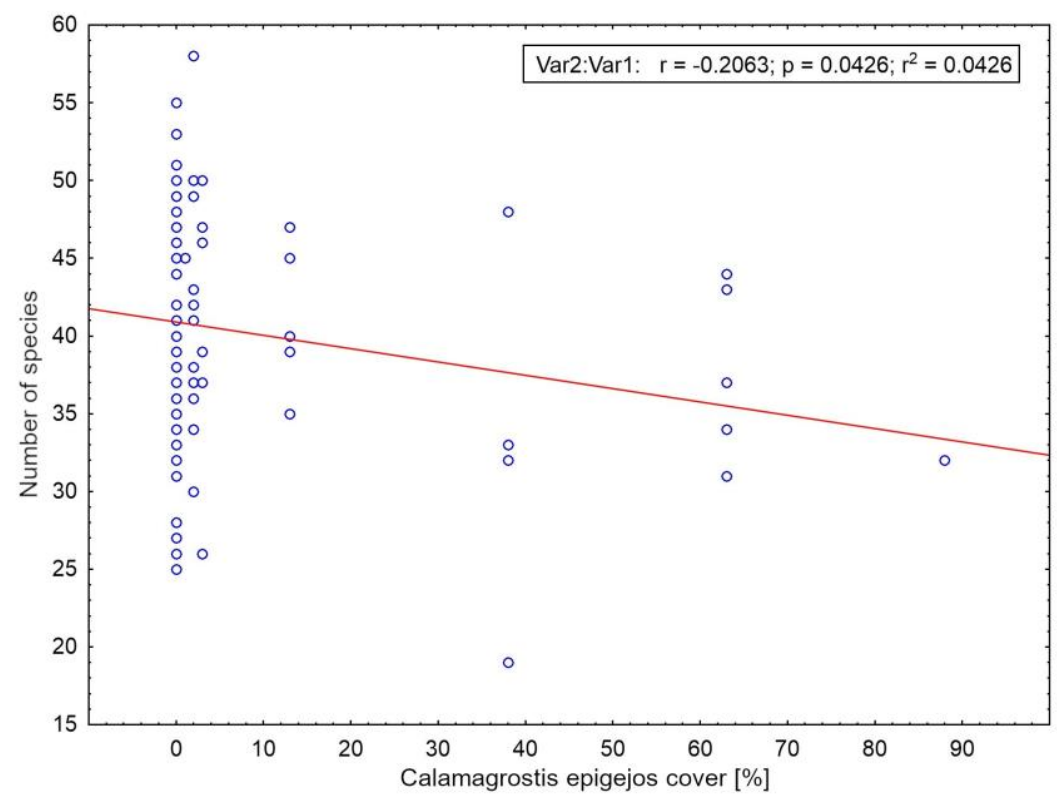

Changes of abundance of woody species (seedlings of pioneer trees, ramets of clonal shrubs) indicate the progress in secondary succession towards climax community - i.e. forest. Transition of grassland type of old-fields to the stands with relevant proportion of shrubby floor is "practical" problem associated with management practices. Histogram of the old-field age suggests the highest proportion of abandonment 20 and more years ago (Fig. 9). This category of abandoned land logically includes frequent old-fields with the presence of shrubs and seedlings of trees. Protection of herb diversity by the individual shrubby consorcia continuously changes up to the huge canopy of shrubby floor and high shading when decline of plant diversity starts. 
Veselý A., Vojta J., Kovář P.: Arable land abandonment in the Czech villages of Romanian Banat area and plant diversity in old-fields

Fig. 9: Age structure of the recorded vegetation localities within old-fields indicates the waves of people emigration from the region

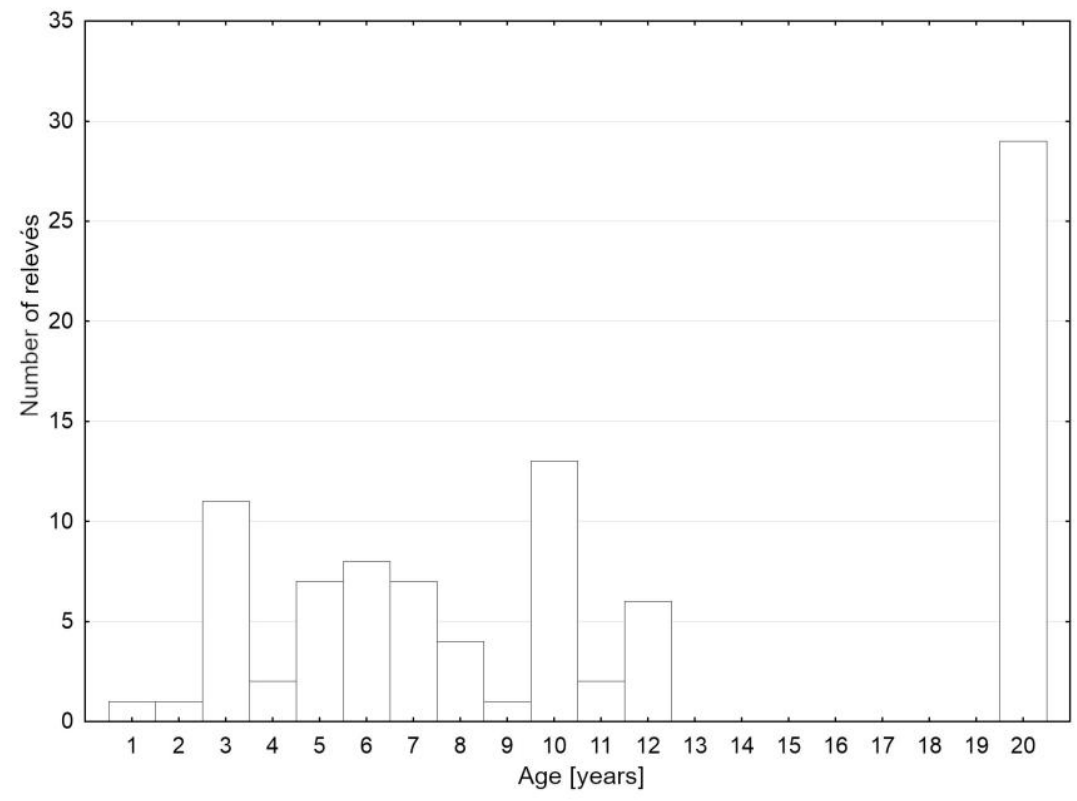

Fig. 10: Dependence of alpha diversity (number of plant species) on the age of old-fields (adapted according to Kovár et al., 2014).

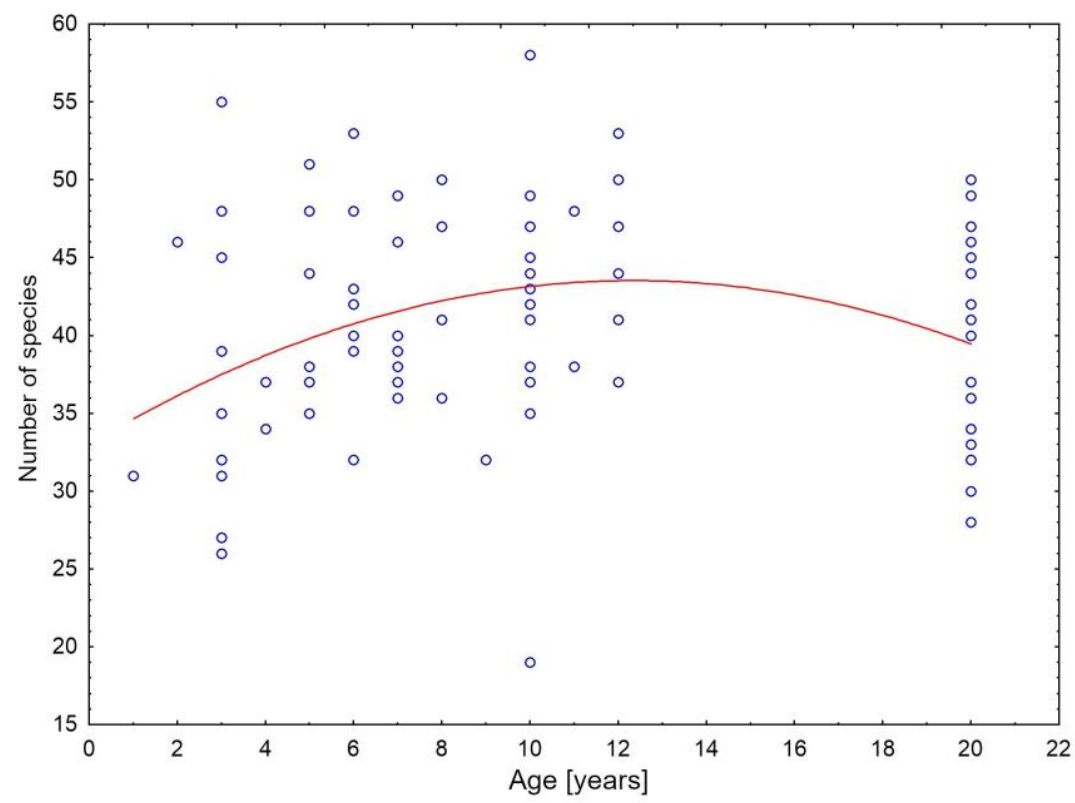


However, shrubs are frequent in plots influenced by periodic burning and also in intensively grazed pastures. Both cases imply limitation of herb floor competition and nutrient rich mosaic of the upper soil layer supporting the increase of plant number by this way until the stress threshold. Dependence of alpha diversity and/or species number in old-fields on their age presents a unimodal shape with the maximum of species diversity roughly around 13 years after the land abandonment (Fig. 10). Null hypothesis of constant alpha diversity independent on the age of old-fields was rejected $(\mathrm{p}=0.0195)$. On the other hand, the hypothesis of the unimodal course of the tested function is impossible to reject $(\mathrm{p}=0.0753)$.

\section{DISCUSSION}

This paper includes more data connected with habitat conditions of studied old-fields than another one published from the territory earlier (Kovár et al., 2014). Testing of the environmental parameter's significance in their influence on the communities within new combination of measured factors rearranged them as above commented figures demonstrate. While Heat Load Index lost in its significance (this article), the soil chemistry newly analyzed, mainly $\mathrm{C} / \mathrm{N}$ ratio, appeared as the higher indicator explaining vegetation development of the old-fields. More new knowledge of the soil conditions in this carst area represents good support for this pronouncement (Zajícová et Chuman, 2019; Kučera et al., 2019).

The data about the length of abandonment and the type of management in the particular period for individual old-fields were obtained from interviews with inhabitants and/or land owners from the village of Sfânta Elena (other sources such as satellite imagery of suitable quality or document papers and/or maps are not available). Credibility of these informations is relatively high when we confront the pattern of the old-fields in the studied macrolocalities with cumulation of the parallel strips of abandoned or partly cultivated fields. The scheme is commonly rotating with the periodically following structure of field „clusters“ with the sequences of various age where an actual phenomenon is observed of the shortening maximum distance from the village of definitely abandoned fields and their transformation into pastures (such type of grassland stands are included also into the study of Řepka et al., 2014). Example of records of the field age obtained from local people is the following: macrolocality „X“ - old-field 1: age 3 yrs, old-field 2: age 10 yrs, old-field 3: age 5 yrs, old-field 4: age 7-8 yrs, field 5: arable land, old-field 6: age 10-12 yrs, old-field 7: age 15-18 yrs, old-field 8: age 20 and more yrs,... A kind of problem is represented by the eldest old-fields the duration of the abandonment of which coincides with the vawes of people escaping (during the 1960 s, immediately after 1989, at present time etc.). In our data, the category of the oldest abandoned fields is mostly localized at two macrolocalities (wider surrounding of the „Danube vantage point“ (south of the Sfânta Elena village) and adjacent land to former shepherd's hut near the secluded place of „Liboraz“ (NE of the Sfânta Elena village). They represent different ecological conditions and regimes, in the first case low elevations close to the Danube River with predominant grazing, in the second case relatively high elevations with intensive burning impacts and soil erosion. The number of relevés taken from the two mentioned localities represents $1 / 6$ of the total amount of vegetation records. They could be categorized more weakly, e.g. 15-25 years where 20 represents probable average of their age. However, the main conclusion about the diversity optimum found at intermediate successional stages of the old-fields is not affected substantially and is responding to basic experience presented in many publications (e.g., Bomberger et al., 1983; Osbornová et al., 1990; Cramer et Hobbs, 2008; Prévosto et al., 2011). 
Veselý A., Vojta J., Kovář P.: Arable land abandonment in the Czech villages of Romanian Banat area and plant diversity in old-fields

The oldest successional stages of local old-fields are of two characters - dense compact grasslands and stands with shrubby dominants. While extensive pasture on the long-term abandoned fields (twenty and more years) leads to relatively high cumulation of leaf litter and its cushion creates a kind of barrier on the soil surface for the establishment of pioneer tree seedlings (e.g., Carson et Petersen 1990), repeated burning doesn't represent an effective barrier for spreading the shrubby floor of clonal shrubs and trees shading the herb layer and outcompeting herbs by this way - open soil surface then favours rather annuals (e.g., Daubenmire, 1975; De Steven, 1991). The second case in the studied area shows the presence of woody plants such as Crataegus sp. div., Rosa sp. div., Rubus sp. div., Pyrus communis juv., etc.). The empirical data demonstrate the dependence of the shrub cover with the mentioned genus/species dispersion on the age of the studied old-fields (Kovár et al., 2014). Importance of particular factors on the structural pattern and successional progress within the trend to woody plant floor in open vegetation formations was, in general, treated by many authors, e.g., Omacini et al., 1975; Prach et al., 2007; Dinnage, 2009; especially Ruprecht, 2005 or Vojta et al., 2014 for Romanian environmental contraints.

\section{CONCLUSIONS}

Influence of the key ecological factors and/or type of management on the plant composition of the old-fields suggests a significance order as follows: 1 . the carbon/nitrogen ratio of soils, 2. available soil phosphorus, 3. total soil nitrogen, 4. burning management and 5. time of land abandonment (age). The other variables (grazing, mowing, zero management) do not exhibit effective impact according to our dataset and seem to be equal to the absence of burning.

Successional transition of the old-fields into the two-floor structured (shrubby) vegetation is manifested by old-fields abandoned for approx. 20 years, especially by those repeatedly burnt which type of disturbance favours the establishment of woody plant seedlings and growing progress due to fire damage resistance, mainly of clonal shrubs. Burning disturbance is typical phenomenon indicated by combination of plant adaptive strategies from short-lived ephemerophytes to resistent woody representatives.

Evenness of plant species composition in the old-field communities is not connected with their length of abandonment, i.e., the dominants don't assert more on elder old-fields than on the younger ones. Evenness exhibits only clear dependence on the $\mathrm{C} / \mathrm{N}$ ratio in the soils.

Dependence of number of plant species (alpha diversity) on the abandoned field's age displays a unimodal shape of this relationship with the maximum of species diversity in plant stands aged approximately 13 years.

\section{ACKNOWLEDGEMENT}

The work was supported by the Operational Programme Education for Competitiveness "Creation and development of a multidisciplinary team on the platform of landscape ecology" (CZ.1.07/2.3.00/20.0004) with the contribution of EU resources and resources from the state budget of the Czech Republic. 


\section{REFERENCES}

Bazzaz, F.A., (1975). Plant species diversity in old-field successional ecosystems in southern Illinois. - Ecology, 56: 485-488.

Bomberger, M.L., Shields, S.L., Harrison, A.T. and Keeler, K.H., (1983). Comparison of old field succession on a tallgrass prairie and a Nebrasca Sandhills prairie. - Biological Sciences, University of Nebrasca - Lincoln, 3(1): 9-15.

Braun-Blanquet, J., (1928). Pflanzensoziologie. Springer Verlag, Berlin.

Carson, W.P. and Peterson, C.J., (1990). The role of litter in an old-field community: impact of litter quantity in different seasons on plant species richness and abundance. - Oecologia, 85: 8-13.

Ciocârlan, V., (2000). Flora ilustratã a României. Pteridophyta et Spermatophyta. 2nd edition. - Editura Ceres, Bucuresti.

Cramer, V.A., Hobbs, R.J. and Standish, R.J., (2008). What's new about old fields? Land abandonment and ecosystem assembly. - Trends in Ecology \& Evolution, 23(2): 104-112.

Csergö, A.M. and Demeter, L., (2012). Plant species diversity and traditional management in Eastern Carpathian grasslands. - EFNCP Report No 3150755, Derwentside, England, p. 4-41.

Daubenmire, R., (1975). Plant succession on abandoned fields, and fire influences, in a steppe area in Southeastern Washingthon. - Northwest Science, 49(1): 36-48.

Denslow, J.S., (1980). Patterns of plant species diversity during succession under different disturbance regimes. - Oecologia, 46: 18-21

De Steven, D., (1991). Experiments on mechanisms of tree establishment in old field succession: Seedling survival and growth. - Ecology, 72: 1076-1088.

Dinnage, R., (2009). Disturbance alters the phylogenetic composition and structure of plant communities in an old field system. - PloS ONE, 4(9): 1-9.

Greenfield, K., (2005). Light disking to enhance early successional wildlife habitat in grasslands and old fields: Wildlife benefits and erosion potential. - Technical Note No. 19032, The U.S. Department of Agriculture (USDA), NRCS, Washington, D.C., p. 1-9.

Kováŕ, P., Veselý, A., Vojta, J., Wiesner, P., Drhovská, L. and Klárová, M., (2014). 5.3 Consequences of arable land abandonment for the diversity of plant communities.- In: Maděra P., Kovář P., Romportl D., Buček A. et al (Eds): Czech villages in Romanian Banat: Landscape, nature, and culture.(p. 164-175) - Mendel University in Brno, 2014.

Kučera, A., Marosz, K., Holík, L. and Dundek, P., (2019). World under the feet - soils and bedrock. - In: Kováŕ P. (Red.): Transferred countryside (p. 146-163). A Czech rural phenomenon in the Romanian Banat territory. - Academia, Prague, 2019 [in Czech].

Maděra, P., Kovář, P., Romportl, D., Buček, A. et al (Eds), (2014). Czech villages in Romanian Banat: Landscape, nature, and culture. - Mendel University in Brno, p. 348.

McCune, B. and Keon, D., (2002). Equations for potential annual direct incident radiation and heat load. - Journal of Vegetation Science, 13(4): 603-606.

Omacini, M., Chaneton, E.J., León, R.J.C. and Batista, J.B., (1975). Old-field successional dynamics on the inland pampa, Argentina. - Journal of Vegetation Science, 6: 309-316.

Osbornová, J., Kováŕová, M., Lepš, J. and Prach, K. (Eds.), (1990). Succession in abandoned fields: Studies in Central Bohemia, Czechoslovakia. - Kluwer, Dordrecht.

Prach, K., Lepš, J. and Rejmánek, M., (2007). Old field succession in central Europe: Local 
Veselý A., Vojta J., Kovář P.: Arable land abandonment in the Czech villages of Romanian Banat area and plant diversity in old-fields

and regional patterns. - In: Cramer V.A. and Hobbs R.J. (Eds.): Old fields. Dynamics and restoration of abandoned farmland (pp. 180-201). - Island Press, Washington, 2007.

Prévosto, B. et al., (2011). Impacts of land abandonment on vegetation: Successional pathways in European habitats. - Folia Geobotanica, 46(4): 303-325.

Pyšek, P. et al., (2012). Catalogue of alien plants of the Czech Republic (2nd edition): checklist update, taxonomic diversity and invasion patterns. - Preslia , 84: 155-255.

Roleček, J., Tichý, L., Zelený, D. and Chytrý, M., (2009). Modified TWINSPAN Classification in Which the Hierarchy Respects Cluster Heterogeneity. - Journal of Vegetation Science, 20(4): 596-602.

Ruprecht, E., (2005). Secondary succession in old-fields in the Transylvanian Lowland (Romania). - Preslia, 77: 145-177.

Řepka, R., Šebesta, J., Maděra, P. and Koutecký, T., (2014). 5.1 Semi-natural dry grasslands of the White Carpathians and the Banat region: A comparison of the floristic composition and species richness. - In: Maděra P., Kovář P., Romportl D., Buček A. et al (Eds): Czech villages in Romanian Banat: Landscape, nature, and culture (p. 144-152) - Mendel University in Brno, 2014.

Schmitz, O.J., Kallies, E.L. and Booth, M.G., (2006). Alternative dynamic regimes and trophic control of plant succession. - Ecosystems, 9: 659-672.

Siemann, E., Haarstad, J. and Tilman, D., (1999). Dynamics of plant and arthropod diversity during old field succession. - Ecography, 22: 406-414.

Štolcová, J., (2002). Secondary succession on an early abandoned field: Vegetation composition and production of biomass. - Plant Protection Science, 38(4): 149-154.

ter Braak, C. and Šmilauer, P., (2002). Canoco reference manual and Canodraw for Windows user's guide: software for canonical community ordination, version 4.5. Microcomputer power, Ithaca, NY, US.

Tichý, L., (2002). JUICE, software for vegetation classification. - Journal of Vegetation Science, 13: 451 - 453.

Veselý, A., (2016). Phytodiversity in old fields of different age and management history on agricultural land adjacent to Czech villages in Romanian Banat area. - MSc Thesis [Charles University in Prague, Faculty of Science, Institute of the environment], 82 p. [in Czech]

Vojta, J., Kováŕ, P. and Volařík, D., (2014). 5.2 Patterns of grazing and plant species diversity in the pasturelands. - In: Maděra P., Kovář P., Romportl D., Buček A. et al (Eds): Czech villages in Romanian Banat: Landscape, nature, and culture (p. 153-163) - Mendel University in Brno, 2014.

Wilsey, B.J. and Potvin, C., (2000). Biodiversity and ecosystem functioning: Importance of species evenness in an old field. - Ecology, 81: 887-892.

Zajícová, K. and Chuman, T., (2019). Effect of land use on soil chemical properties after 190 years of forest to agricultural land conversion. - Soil \& Water Res., 14: 121-131.

\section{Web site:}

http://www.synbiosys.alterra.nl/turboveg/

http://www.sci.muni.cz/botany/juice.htm 